\author{
Asian Journal of Contemporary Education \\ $\operatorname{ISSN}(e): 2617-1252$ \\ DOI: 10.18488/journal.137.2021.51.1.11 \\ Vol. 5, No. 1, 1-11. \\ (C) 2021 AESS Publications. All Rights Reserved. \\ URL: www.aessweb.com \\ check for
updates
}

\title{
GROUNDED THEORY RESEARCH: TEACHING FOR MASTERY IN WRITING ABILITY AS A SKILL
}

\section{David BLASCO}

Ming Chuan University, Taipei, Taiwan. Email:dblasco1970@gmail.com Tel:988376010 (i) Check for updates

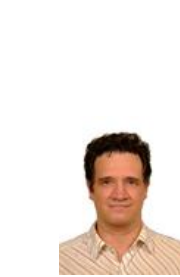

Article History

Received: 16 November 2020 Revised: 18 December 2020 Accepted: 4 January 2021

Published: 25 January 2021

\section{Keywords}

Grounded theory Pedagogy skills Questioning strategies Individual characteristics Resilience.

\begin{abstract}
The purpose of this study was to investigate the needs of students to improve their ability in writing essays in English. One hundred and three students were surveyed after three months after starting classes on fall semester of 2020. A qualitative research approach based on Grounded Theory was used throughout the research process. The data analysis gave rise to a process leading to a core category which shows how students can reach a higher level of writing ability as a skill. Three different categories were identified as being important for gaining a writing ability as a skill, namely, the teacher pedagogy skills, questioning strategies and individual characteristics. Instructors should organize lessons in small steps to achieve a learning goal. At the same time, they have to make sure students comprehend not only directions of learning activities but also the concepts they are working on. In addition, educators must support and encourage to each student by showing warm feelings and focusing on helping student to maintain a satisfying flow of communicative competency. If these requirements were met, students' ability in writing essays would be increased. Writing as a skill can be reached when students feel that they are treated fairly, with patience and attention. Instructors should be aware of these needs and should treat students as individuals and thus to help them to achieve higher levels of competency.
\end{abstract}

Contribution/ Originality: This study contributes to the existing literature by investigating students' insights to improve their mastery in writing ability as a skill in Taiwan.

\section{INTRODUCTION}

The researcher found only one research related to College students' writing self-efficacy conducted in China (Sun \& Wang, 2020). Although Teng (2020) wrote that universities' responsibility is to help students develop the ability to cope with academic and social difficulties they may encounter in their lives, there is a scarcity of research related to self-efficacy in china and academic research on this topic is still in demand in Taiwan. In order to fill this important gap in educational research, the present research aimed to define the qualities teachers must possess to improve his students' writing ability as a skill. This study found that a theory triangulating pedagogical tasks, questioning strategies and individual characteristics are essential factors to help students become resilient and successful writers. 


\section{LITERATURE REVIEW}

First and foremost, what is generally understood by "students' writing ability as a skill”? Bandura (1993) explained that intellectual skill and intellectual aptitude will differ students on how they perceive and manage their self-efficacy. Students' resilience was fostered when they had a conception of ability as an acquired skill. On the other hand, students' perceived sense of ability decreased when they view ability as an intellectual aptitude. When students reflect on their study as an intellectual aptitude to perform a written activity they develop a belief that their aptitude is quite low. Therefore, they should change minds into viewing their ability as a skill that must be developed and practiced to achieve higher attainments. According to Teng (2020) the Taiwanese educational system brings too much emphasis on “credentialism". The writer simply means that students' learning aptitudes and academic achievements are only valued to maintain the school's position in national rankings. Consequently, students' life skills and emotional intelligence are considered as being unnecessary in regards to the students' school life and performance. According to Teng, that should not be so because education cannot be separated from life and society. Social and emotional skills are an integral part of any competencies (Tsai, 2020). In order to improve students' writing ability as a skill, teachers must observe and improve three important areas of their teaching philosophy. These areas take into consideration the teacher's implementation of pedagogical tasks, questioning strategies and his individual characteristics.

\subsection{Teacher's Implementation of Pedagogical Tasks}

Task-Based Language Teaching (TBLT) is one of the most important perspectives within the CLT framework (Brown \& Lee, 2015). TLBT includes a series of tasks defined as "a piece of work undertaken for oneself or for others, freely or for some rewards" (Hismanoglu \& Hismanoglu, 2011). Pedagogical tasks are tasks that occur in the classroom (Brown, 2014) and "tasks are an activity which requires learners to use language with emphasis on meaning, to attain an objective" (Brown \& Lee, 2015). Thus, students "will master how to make full use of their own communicative abilities to shift from L1 to the target language” (Hismanoglu \& Hismanoglu, 2011). They will als develop practical skills to face real-world situation, explore ideas from a personal perspective and build their own metacognition (Wilson \& Conyers, 2013a). Wilson. and Conyers (2016b) advised teachers to set a goal and keep planning in mind. To do so, the educator elaborates tasks that might involve analyzing, planning and organizing ideas.

First, the teacher must establish clear intent of the lesson. To do so, teachers may use explicit statements of goal and expectations. The teacher must state the learning goals clearly and develop a plan to reach them. Then he can identify and match the students' learning needs according to the plan already set. Second, the teacher must develop detailed action plan for progressing in a positive direction. That is to say, the big plan will be achieve by using small steps. Students are lead to learn that big goals must be completed with small and manageable steps so they can make progress regularly. Third, the teacher must focus on executing the action steps in the plan. Fourth, teachers must assess monitor, and adjust their thoughts and actions as they execute their plan and after they complete each action plan. It is recommended that educators give more freedom to students to decide what they will research and study and how they will convey what they have learned. That way, they will be motivated to complete their task successfully. Finally, educators aim for steady gains in a positive direction and look for ways to improve the process.

\subsection{The Teacher's Questioning Strategies}

Teachers need to make sure that students not only understand instructions they give students with Instruction checking questions (ICQs), but also that they understand the learning materials with relevant Concept Checking Questions (CCQs) that they must design before class to maintain continuing interactions with their students. (Brown, 2014) referred to Lev Vygotsky's theory of human mental development to explain that "language is not 
only an instrument for thoughts; it is also an ability that develops through social interactions". According to Hokanson (2018) people build a social network to discuss different matters related to social and academic life. People may build a network of colleagues and groups to work with. It is thus important to pay attention to our reactions or critique of ideas as well as when we receive some feedback or people share ideas with us. As can be seen in Table 1, we can design CCQs to make sure people understand what we want to convey. Workman (2006) design 10 rules regarding the design and use of CCQs:

Table-1. Rules for the design and use of CCQs.

\begin{tabular}{c|l}
\hline 1 & Break down the concept of the item into a series of statements of meaning \\
\hline 2 & Make sure the statements of meaning are expressed in simple language. \\
\hline 3 & Turn the statements into questions, incomplete sentences or questions with a binary choice. \\
\hline 4 & The questions should be concise and simple \\
\hline 5 & The language you use must be simpler than the language you are checking \\
\hline 6 & The questions should not normally use the language you are checking \\
\hline 7 & Sort the questions into a logical order \\
\hline 8 & Write down the correct answers you expect the learners to give \\
\hline 9 & The answer should be short and simple \\
\hline Source: Workman (2006). & If they answer incorrectly, state the correct answer and provide clarification \\
\hline
\end{tabular}

CCQs can actually be used with a lot of flexibility. Constantinides (2013) wrote that they are not only used to check an audience's comprehension in a lecture or a seminar, but are also used for the presentation vocabulary or grammar in order to check its understanding. Table 2 shows a variety of examples to design CCQs.

Table-2. Design and use of CCQs.

\begin{tabular}{|c|c|}
\hline \multirow{3}{*}{$\begin{array}{l}\text { Checking an audience's } \\
\text { comprehension in a lecture or a } \\
\text { seminar, or even a classroom }\end{array}$} & Could you open the door for me, please? \\
\hline & Is this an order or a request? (Request) \\
\hline & Am I being polite or impolite (Polite) \\
\hline \multirow{3}{*}{$\begin{array}{l}\text { Presentation vocabulary } \\
\text { grammar in order to check its } \\
\text { understanding }\end{array}$} & Pictures (Which one shows the word?), \\
\hline & 2. Time lines (Which time line fits this sentence?), \\
\hline & $\begin{array}{l}\text { 3. Physical activity like miming or demonstrating, opposites, } \\
\text { synonyms, definitions, examples, explanations, and even asking } \\
\text { for a translation in the mother tongue or asking the learners to } \\
\text { say which translation is the most appropriate. }\end{array}$ \\
\hline
\end{tabular}

Sources: Workman (2006); Constantinides (2013).

The design and implementation of CCQs in the classroom plays a significant role to perpetuate interactions with students. Brown and Lee (2015) wrote that:

Questioning strategies are the most important key to creating an interactive language classroom is the initiation of interaction by the teacher. However nondirective your style is, the onus is on you to provide the stimuli for continued interaction.

According to Brown and Lee (2015) students will not engage in classroom interaction when teacher ask questions such as "Does anyone understand?" and Workman (2006) defined the term of Concept Checking Questions (CCQs) as an effective way of checking if learners have understood something. Instead of just asking "Do you understand?", "Do you have any questions" or "Is this clear?", teachers have the possibility to ask more pertinent questions. The reason for this is that students may not only think that they have understood the lesson content although they may have misunderstood it, but also may be apprehensive to say openly that they are experiencing difficulties in the lesson target. CCQs are to be used during the lesson to check the students' understanding of the lesson. These questions are quite important to use when the language is complex, does not exist in the learner's language. Therefore, they could be particularly useful when both the teacher and students' native language is different from the language target because "when different persons speak different languages, the 
chance of misinterpretation is compound" (Fisher \& Ury, 2012). Second, CCQs are very convenient to use. Once teachers know the CCQs for a particular use, they will remain the same and will always be ready to use. Finally, educators will have the possibility to develop their language awareness skills

\subsection{Individual Characteristics}

Each student need attention and care in their study, thus skillful interpersonal communication has become an essential part of the teacher's teaching practice. Teachers' responsibility is not only to provide feedback, but also to be mindful in his teaching and to provide support and encouragement to each student (Dörney and Csizér cited in (Spratt, Pulverness, \& Williams, 2011)).

According to previous research, teachers need to provide feedback on errors, on improving styles and writing skills. But communication is about creating connections with one another, which is the essence of human life. The four languages skills, include two language comprehension skills, listening and reading, and two production skills, speaking and writing (Spratt et al., 2011). Therefore, communication is a complex, dynamic, transactional process. In order to simplify this process, Brown and Lee (2015) wrote that the most important aspect of feedback is to help students maintain a satisfying flow of communicative competency. To do so, instructors should give freedom to students making self-correction, avoiding over correcting them to respect their feelings and to increase their confidence in their communicative abilities. By contrast, grammatical and spelling errors should be treated differently. Teachers should remember that errors that impede meanings must be pointed out as soon as possible to avoid fossilization. Regarding students' writing styles, Brown and Lee (2015) wrote that, on the one hand, teachers must respect academic requirements that programs value for their students. On the other hand, it is recommended that teacher "preserve the voice of a writer". The reason for this is that students' writing may take unique styles of expression. Thus the teacher's teaching skill is to be aware of when and how to make corrections because speaking and writing alike are very personal productions that teachers should respect and preserve. Finally, teachers can help their students improve their skills by showing patience when providing positive feedback on how they can improve their language communication skills. According to Wilson and Conyers (2013a) students need concrete examples from successful people to learn how to achieve a task more efficiently. According to Brown and Lee (2015) instructors must provide support and encouragement to their students after assigning a task to their students. They stated that the teacher's responsibility is to monitor the task and to help or a guide them. It makes thus sense that every teacher must let students know that they are available to answer questions and to make suggestions to keep them on track. It is also recommended that instructors pay attention to students' effort, not just their results Wilson and Conyers (2013a) such as asking students to complete simple rating forms on how they did individually and as a group planning, researching and doing their projects. Teachers and students may discuss and decide what they might do differently on their next project (Wilson. \& Conyers, 2016b).

Finally, students also appreciate receiving approvals from their teachers and entourage after having completed their task successfully. On the other hand, it is essential for the teacher to adapt their teaching methodology to match their learning styles and needs. It is well-known that teacher must develop mindfulness and the literature is well documented on this aspect. For example, Siegel (2007) wrote that "mindfulness is a form of healthy relationship with oneself. Being mindful is a way of becoming your own best friend". On the other hand, teachers must also become aware of their audience. Bowden (2010) explained that "presenters must show genuine acceptance of their audience to have their presentation accepted". But it is highly likely that most teachers may not have received this kind formal training in their teaching practice and may remain uncertain on how to achieve this level on communicative competence. It is fortunate that Brown and Lee (2015) have provided examples of Verbal communication and Non-verbal communication. Verbal communication means that teachers are able to project their voice and hat their lectures are intelligible. students can hear lectures clearly because the teacher articulates can control the flow of his speech in an unrestrained or heartfelt way (Brown \& Lee, 2015). instructors may also reveal 
their real feelings when facing their audience. It is preferable that they display warm feelings by adopting an air of confidence with positive facial and body attitudes. That way, they can appreciate their students when they make frequent eye contact with them and moving around the classroom to reach to them. It goes without saying that teachers also need to follow conventional rules such as social distance, dressing appropriately and the respect of the teacher-student relationship (Brown \& Lee, 2015). According to the literature, we are forced to recognize that the strengthening of students' confidence in their writing ability as a skill is subordinated to the triangulation of teacher's pedagogical skills, questioning strategies and his individual characteristics

\section{RESEARCH METHOD}

\subsection{Significance of the Study}

The aim of this study was to investigate the needs of students to improve their mastery in writing essays as a skill in English. That is to say, instructors can help students become more resilient in the learning process.

\subsection{Sample \& Data Collection Method}

This interview study with a qualitative research was conducted at Ming Chuan University in the fall semester of 2020 based on Grounded theory. In their book title Basics of Qualitative Research: Techniques for Developing Grounded Theory (2015), Corbin \& Strauss described Grounded Theory as having the purpose to construct theory grounded in data. Therefore, this study gathered data from a sample of participants which included 103 students recruited from two English classes. One class named "English Business Communication" was composed of 70 students ( $\mathrm{N}=27$ males and 47 females), while another class named "composition 3" was composed of 33 students $(\mathrm{N}=13$ Males and 20 females). Both class had writing tasks to complete. The former required students to write narrative paragraphs. The latter was required to complete three academic essays including one explanatory essay, one "cause and effect essay” and one "compare and contrast essay".

\subsection{Instruments}

This study first collected raw data with two preliminary questionnaires including "MCU teacher observation record" and Sun \& Wang's self-efficacy questionnaire (2020) to experience and understand what is happening in the classroom (Corbin \& Strauss, 2015). Then several interviews were conducted with students after they completed their midterm exams. All the students who agreed to talk about their learning experience to the teacher-researcher. Data were collected through semi-structured interviews. All interviews were tape-recorded and the teacherresearcher transcribed them verbatim. Each interview was opened by checking students' homework and performance on their study. This allowed students to speak according to their learning perspectives and to tell about their experience in their own words. Students were then free to reflect on their study and to express their feelings and suggest ideas on how they could improve their writing ability.

\subsection{Data Analysis}

The raw data collected was analyzed following Corbin and Strauss's research directions including the theoretical sampling, memos, coding and concepts for data analysis. Following Corbin and Strauss (2015) recommendations on Theoretical samplings, data collection stopped when no new information could be gained from the interviews. According to Corbin and Strauss (2015) recommendations on conducting a qualitative data analysis, this study began with an observation and a questionnaire to "identify relevant concepts, validate them, and explore them more fully". Only then, more meaningful raw data could be gathered to form theoretical sampling. That way, the teacher-researcher could construct an in-depth and broad theory. After each interview, the teacher-researcher not only analyzed and categorized the data, but also summarized it into concepts in his memos. 


\section{RESULTS}

The data analysis gave rise to a process leading to a core category which showed how students can attain a writing ability as a skill. Three different categories were identified as being essential for students to reach this skill, namely the teacher's questioning strategies, his individual characteristics and the implementation of his pedagogical tasks. Questioning strategies means that instructors ask relevant to the students to see that they understand the materials and concepts covered in class. Instructors must also make sure that the students feel comfortable with the learning pace and that they have time to comprehend the learning content. In addition to this, the instructor must also monitor students' learning by providing feedback on their learning. If all these conditions are met students could gain more confidence in their writing ability.

\subsection{Core Category - Writing Ability as a Skill}

A writing ability as a skill is defined by Bandura (1993) as an ability to develop resilience while trying to overcome the challenge of completing a writing task. The categories found in this study are not areas of improvements to be used independently by instructors. Rather, instructors should use them simultaneously. Organizing lesson plans efficiently (i.e. with goal setting processes) makes students feel more comfortable in their study and can help them develop a sense of autonomy and trust that they are able to achieve the learning targets set by the instructors. Students thus can develop a sense of resilience (Bandura, 1993) that help them overcome challenges cropping up along the writing process. Teachers who are flexible enough to adopt a new teaching philosophy regarding their questioning strategies, implementation of pedagogical tasks and individual characteristics, will see their students become more efficient at completing their writing assignments as they were able to develop a writing ability as a skill.

\subsection{Implementation of Pedagogical Tasks}

The "Pedagogical tasks" category includes the importance of providing organized teaching plans to the students. By "organized" the teacher-researcher means that the students understand all the concepts included in the lesson and are able to complete all the requirements of the tasks. Fortunately, not only less efficient students can beneficiate from more organized lesson plans, but also more efficient students because all the learners are highly likely to learn how to improve their writing skills.

One the one hand, interviews revealed that most students lack practice in writing and the teacher needs to adjust his teaching methodology to compensate for this learning disadvantage. Three students expressed a feeling of uneasiness when they mentioned:

I lack practice in writing in English. I keep repeating the same errors over and over again.

I don't take initiative to write; I just try to complete assignments. I feel I don't have enough time to spare to pay attention on this study.

I am not used to write in English and I don't consider things that happen in my life are so important enough to be recorded or remembered in a diary or journal.

Two students mentioned that students usually do not put enough efforts in their study by saying: Our English is not good enough to understand everything. Some students also do not work hard enough. So they don't pay attention to their study. They will review the lessons' contents covered in class only if need at a last resort.

We are not interested in checking MOODLE regularly. We only check when teachers give us homework. I check my scores, but I only check the content of the lessons covered in class at least once a month 
On the other hand, interviews also revealed that two students expressed a feeling of contentment when they said that:

I pay attention and hand in my essays on time; I take notes and I know what I have to do.

I have become familiar with writing because I am used to write a diary.

One student pointed out how to help learners gaining more confidence in their study and achieve greater success in their study when she said:

You can write the most important sentences, the key points and key words. We understand. But

English level is not high enough so we can't understand automatically during class time - we

need time to understand. Need to do some adjustments - to the point.

Thus, it appears that instructors can boost their students' comprehension by developing a curriculum designed to enable students to achieve the learning targets at a regular pace. Students must feel that they are able to complete one task at a time on a regular basis to reach the learning objective. To do so, instructions can "get to the point" by not only providing more examples of sentence patterns to increase vocabulary base and review grammar points with guidance for solving problems, but also by helping students understand concepts by building knowledge based on previous learning tasks.

\subsection{Questioning Strategies}

The "Questioning Strategies" category includes two subcategories of questions. Instruction Checking Questions (ICQs) are questions that are relevant and focused on the ability for students to understand instructions, while Concepts Checking Questions (ICQs) are questions about key concepts to reach the learning goal. In this study, students expressed the need for teachers to care about their difficulties in English writing. As a matter of fact, this study revealed that the most important action that teachers should take, beside repeating instructions, is to provide them with more writing examples to review to support their study. A great majority of students revealed that their difficulties does not come from the misunderstanding of instructions and directions, but indeed from a limited range of vocabulary and a resulting inability to write sentences in more details. They expressed a feeling of inadequacy and regret about nothing being done about their difficulties:

Usually, I have problems understanding is because I don't understand the keyword that you say that's mean this is my problem because of my low vocabulary.

I think it is clear as i can understand what teacher wanted. The thing is not every student can

Easily understand by listening or reading becuz of their english level ( im so bad:)).

Instruction Checking Questions (ICQs) are important because several students expressed the need to have clear presentations and many become confused about what the instructions they have to follow:

Speak slowly sometimes I don't understand and maybe misunderstand what the teacher says. So I

lose track of what you are saying and I don't know clearly what you want exactly, your files contain too much English writing, I think we need more simple English word files to clear files with clear tables. You can write the most important sentences, the key points and key words.

Student also need support from their teachers to comprehend learning content and review past lessons with CCQs. CCQs are important because students do not automatically spend time on practicing their writing skills outside of class and may forget basic concepts within a week:

Our English is not good enough to understand everything. Some students also do not work hard enough. So they don't pay attention to their study. They will review the lessons' contents covered in class only if need at a last resort.

\subsection{Individual Characteristics}


The "individual characteristics" category had two dimensions: First, instructors must guide students to gain a satisfying flow of competency and second, they must develop patience and mindfulness. The dimension of guiding students included helping students find ideas to develop their writing, correcting their answers, monitoring their learning activities and the instructor's non-verbal communication with regard to developing writing students' skills:

I often run short of ideas. I don't know what to write because I am not used to write essays on my own.

Taiwan teaching style is to spoon feed students with information. Teachers do not ask us to develop creative. We may not feel motivated to practice writing in English because teachers do not give us any challenging tasks to complete.

All the students said that they expected their teacher to be more patient to explain the tasks more clearly. Students often felt confused they could not gasp the meaning of the instructions given by the teacher:

Some students do not understand what you want us to do. They have to check all the words on their cell

phones and try to understand what they have to do. Sometimes it is difficult because our English is not good enough to understand everything.

According to Ming Chuan Univerty's learning covenant, using cell phones in class during the learning time is a breach of etiquette. Nevertheless, all the students are allowed to bring their smartphones and laptops to class. Although students realize that their use of technology in the classroom is inadequate and does not favor maximization of the learning time, they would still appreciate their teacher to be more mindful when they don't pay attention in class:

We find it hard to concentrate in class because we like to play online games.

We often feel distracted by the noise of electronic devices that students use in the classroom.

We are not interested in checking MOODLE regularly. We only check when teachers give us homework. I check my scores, but I only check the content of the lessons covered in class at least once a month.

\section{DISCUSSION}

The aim of this study was to investigate students' learning needs to gain mastery in writing ability as a skill. Results show that students not only need clear instructions but also their teacher's feedback on writing fluency with guidance and patience. These include the teacher giving step by step goals or progressive learning to achieve the learning goal with care. Care is being mindful and being interested in students' learning progress by asking instruction and concept checking questions.

The three categories discussed under "Writing ability as a skill" are considered essential to students to gain mastery in writing. Previous literature shows that the first category "Questioning strategies" is important in the teaching methodology. Workman (2006) wrote that asking questions is quite important to make sure students understand the learning content when the language used is complex.

Students reported "I have problems understanding is because I don't understand the keyword that you say that's mean this is my problem because of my low vocabulary", they also said "I don't know clearly what you want exactly" and "your files contain too much English writing, I think we need more simple English word files to clear files with clear tables". Thus, the results in this study are in line with Constantinides (2013) and Workman (2006) that speakers should use to check an audience's comprehension in a lecture. Thus, college students also need their instructor to help them improve their comprehension skills by asking relevant questions with context clues to avoids misunderstandings (Fisher \& Ury, 2012). Instructors need to finds ways to regularly ask concise and simple questions to students to check their comprehension on learning content because human beings learn through multiple interactions (Brown, 2014; Hokanson, 2018).

The second category "Implementation of pedagogical tasks", includes the integration of a step by step teaching methodology. According to the literature, the TBLT provides task-based learning activities which includes 
a series of tasks essential to let students achieve success progressively (Brown \& Lee, 2015; Hismanoglu \& Hismanoglu, 2011). During the interviews, respondents revealed "I don't take initiative to write; I just try to complete assignments. I feel I don't have enough time to spare to pay attention on this study"”, "We don't review lessons regularly" while more efficient students said "I pay more attention in class, I take notes and I have become more familiar with writing because I am used to write a diary". Thus, students' writing should focus on improving meaningful communication skills with tasks that require completing a definite objective in the target language (Brown \& Lee, 2015; Hismanoglu \& Hismanoglu, 2011). This can be achieved with a teaching plan allowing students to learn progressively in small steps to real the learning goal set by the curriculum (Wilson \& Conyers, 2013a).

Previous literature shows that the third category "Individual characteristics" includes the two sub-categories of guidance and verbal and non-verbal communication. Instructors' responsibility is to guide students to succeed in their learning by providing support and encouragement to each student (Dörney and Csizér cited in Spratt et al. (2011)). When students were asked "Should the teacher give you more examples of sentences to write your essays? Several agreed and answered "I think if you can give more examples of sentences it can help me to think more and it can help me deeper understanding the writing model' and "Examples do help others to understand better". This is in line with Brown and Lee (2015) who wrote that the most important aspect of feedback is to help students maintain a satisfying flow of communicative competency. Another aspect of this category is that teachers pay attention to students' effort, not just their results (Wilson \& Conyers, 2013a) such as asking students to complete simple rating forms on how they did individually and as a group planning, researching and doing their projects. Teachers and students may discuss and decide what they might do differently on their next project (Wilson. \& Conyers, 2016b).

Most students expressed regret about their inability to write correctly and their lack of habit to write essays in English. Most students said "I Repeat the same mistakes because I don't take initiatives to write. I just can complete my assignments because I don't have much time for anything else" and "I don't consider things that happen in my life are so important enough to be recorded or remembered in a diary or journal so I lack practice in writing in English”. According to Siegel (2007) and Bowden (2010) instructors' duty is to control their Verbal and Non-verbal communication. The reason for this is not only for the instructors to keep a feeling of contentment but also to provide a positive and energetic environment to the students by feeling as they are. That way, students will be more likely to overcome their academic challenges (Teng, 2020).

Because social and emotional skills are an integral part of any competencies (Tsai, 2020) the present study suggests that instructors should pay particular attention to the feedback they provide to their students. When implementing a step-by-step teaching method with regular goals that are at the students' level of competency, instructors should not only provide feedback on writing skills but also pay more attention to their ability to achieve meaningful communicative flow with ICQs and CCQs. It is also essential to support this feedback with positive verbal and non-verbal communication so that students will benefit from a more energetic study environment.

\section{LIMITATIONS}

This study has some limitations which need to be considered. First, the teacher was the only researcher of this study. He did not have enough time to conduct more thorough interviews with all the students to gain more insights for the purpose of gathering raw data. In contrast, this study provides more knowledge of the needs of the students to help them become more efficient in mastering English writing skills. The literature supports the findings of this study, which suggests that this study deserves attention from the educational institutions. According to Bandura (1993) another limitation is that most students may perceive their intellectual skill and intellectual aptitude as being limited. The reason for this is that most of them stated that their communication skills 
are "not good". Although students tried to speak English to the best of their ability, they may have not felt confident enough to express themselves to the researcher.

Due to this factor, all students were interviewed at regular intervals for only thirty minutes by making appointments with the teacher-researcher at his office after their midterm examinations. When the semi-structured interviews started, students were asked to check if all their assignments were completed and if they their scores were indicated on their score card. After this initial stage, students were asked to express themselves on the course content and explain the reasons why they felt they were able to write or not. Finally, the teacher asked students questions according to their comments.

\section{IMPLICATIONS}

Caring for students' learning needs have become a priority and teacher must be ready to adapt their teaching style to the students' learning needs. In this study, the researcher wanted to show that providing written and oral feedback per se on students' spelling and grammatical errors is not enough. In order to help students, gain mastery in writing ability as a skill, instructors should provide step-by-step teaching methodology so that learners can improve their communicative flow steadily. While doing so, instructors can provide positive feedback to their students by asking ICQs and CCQs. Therefore, three subcategories of feedback have been uncovered in this study. First, teachers may point out relevant spelling and grammar errors that impede on meaningful communicative flow. Second, teachers must design relevant ICQs and CCQs to guide students in their study. Finally, the instructor' $\mathrm{s}$ individual characteristics to show patience, support and guidance which play a crucial part in the teaching process. Students will be more likely to develop resilience toward the learning content.

Funding: This study received no specific financial support.

Competing Interests: The author declares that there are no conflicts of interests regarding the publication of this paper.

Acknowledgement: This study could not have been without the participation of the students who showed patience and courage in expressing their ideas to the best of their ability for the benefit of this study.

\section{REFERENCES}

Bandura, A. (1993). Perceived self-efficacy in cognitive development and functioning. Educational Psychologist, 28(2), 117148.Available at: https://doi.org/10.1207/s15326985ep2802_3.

Bowden, M. (2010). Winning body language. New York: Mc Graw Hill Publishers.

Brown, H. D. (2014). Principles of language learning and teaching (6th ed.). NY, USA: Pearson Education, Inc.

Brown, H. D., \& Lee, H. (2015). Teaching by principles (4rth ed.). NY, USA: Pearson Education, Inc.

Constantinides, M. (2013). International teacher development center. Cambridge Celta Blog. A blog created for trainees and tutors on our CELTA courses at CELT. Retrieved from The Cambridge CELTA BLOG https://cambridgecelta.org/ on January 1st.

Corbin, J., \& Strauss, A. (2015). Basics of qualitative research. Techniques and procedures for developing grounded theory (4th ed.). Thousand Oaks, CA: Sage Publications, Inc.

Fisher, R., \& Ury, W. (2012). Getting to Yes. Negotiating an agreement without giving in (3rd ed.). Random House Business Book: London.

Hismanoglu, M., \& Hismanoglu, S. (2011). Task-based language teaching: what every EFL teacher should do. Procedia Social and Behavioral Sciences, 15, 46-52.Available at: https://doi.org/10.1016/j.sbspro.2011.03.049.

Hokanson, B. (2018). Developing creative learning skills: An introduction for learners. New York: Routledge, Taylor \& Francis Group. Siegel, D. J. (2007). Reflections on the mindful Brain. A brief overview adapted from the mindful brain: Reflection and attunement in the cultivation of well-being. New York. 
Spratt, M., Pulverness, A., \& Williams, M. (2011). The teaching knowledge test course (2nd ed.). New York: Cambridge University Press.

Sun, T., \& Wang, C. (2020). College students' writing self-efficacy and regulated learning strategies in learning English as a foreign language. System: An International Journal of Educational Technology and Applied Linguistics, 90, 102-22 1.

Teng, H. Y. (2020). Pupils need life skills, not pressure. Taipei, Taiwan: Taipei Times.

Tsai, C. T. (2020). Curriculum and teaching of core literacy: Wunan Book Publishing Co., Ltd.

Wilson, D., \& Conyers, M. (2013a). Five big ideas for effective teaching. Connecting mind, brain and education research to classroom practice. New York: Teachers College Press.

Wilson., D., \& Conyers, M. (2016b). Teaching students to drive their brains. Metacognitive strategies, activities, and lessons ideas. Alexandria, VA: ASCD.

Workman, G. (2006). Concept questions and time lines: Copy2Teach (2nd ed., pp. 1-14). Kilchberg, Switzerland: Chadburn Publishing. 
Asian Journal of Contemporary Education, 2021, 5(1): 1-11

Views and opinions expressed in this article are the views and opinions of the author(s), Asian Journal of Contemporary Education shall not be responsible or answerable for any loss, damage or liability etc. caused in relation to/arising out of the use of the content. 